\title{
IL-13 deficiency exacerbates lung damage and impairs epithelial-derived type 2 molecules during nematode infection
}

AL Chenery $^{* 1,2}$, S Rosini $^{* 1,2}$, JE Parkinson ${ }^{1,2}$, JA Herrera $^{1}$, Craig Lawless ${ }^{1}$, BHK Chan $^{1,2}, \mathrm{P}$ Loke $^{3}$, AS MacDonald ${ }^{2}$, KE Kadler ${ }^{1}$, TE Sutherland ${ }^{\dagger 2}$ and JE Allen ${ }^{\dagger 1,2}$

Judith E. Allen

judi.allen@manchester.ac.uk

The University of Manchester, AV Hill Building, Oxford Road, Manchester, M13 9PT, United Kingdom.

15 Tel: +441613061347

Tara E. Sutherland

tara.sutherland@manchester.ac.uk

The University of Manchester, Core Technology Facility, Grafton St, Manchester, M13 9NT

20 United Kingdom.

Tel: +44 1613066052

${ }^{1}$ Wellcome Centre for Cell-Matrix Research, Faculty of Biology, Medicine \& Health, Manchester Academic Health Science Centre, University of Manchester, Manchester, United 25 Kingdom.

${ }^{2}$ Lydia Becker Institute for Immunology \& Infection, Faculty of Biology, Medicine \& Health, Manchester Academic Health Science Centre, University of Manchester, Manchester, UK.

${ }^{3}$ Laboratory of Parasitic Diseases, National Institute of Allergy and Infectious Diseases, National Institutes of Health, Bethesda, MD, USA.

* These authors contributed equally.

$35 \dagger$ Joint communicating authors

The authors declare no conflicts of interest. 


\section{Abstract}

IL-13 plays a key role during protective type 2 immune responses at mucosal sites, such as during infection with nematodes. However, dysregulation of IL-13 can also contribute to the pathogenesis of atopic and fibrotic diseases such as allergic asthma. Matrix remodelling is an important component of repair processes in the lung but also a hallmark of chronic conditions involving fibrosis. Hence, understanding the role of IL-13 in tissue remodelling has important clinical implications. Since IL-13 shares receptors and signalling pathways with IL-4, disentangling the relative contributions of these type 2 cytokines has been challenging. Additionally, little is known about the singular role of IL-13 following acute tissue injury. In this study, we used Nippostrongylus brasiliensis infection as a model of acute lung tissue damage comparing responses between WT and IL-13-deficient mice, in which IL-4 signalling is intact. Importantly, we found that IL-13 played a critical role in

50 limiting tissue injury and haemorrhaging in the lung following infection. Through proteomic and transcriptomic profiling, we identified IL-13-dependent changes in matrix and associated regulators. We further showed that IL-13 is required for the induction of epithelial-derived type 2 effector molecules such as RELM- $\alpha$ and surfactant protein D. Pathway analyses predicted that IL-13 was heavily involved in the induction of cellular stress responses and regulation of lung epithelial cell differentiation by suppression of Foxa2 pathways. Thus, we propose that IL-13 has tissue-protective functions during lung injury and regulates epithelial cell responses during type 2 immunity in this acute setting. 


\section{Introduction}

IL-13 is a central effector cytokine with diverse roles during both protective and pathogenic type 2 immune responses. During anti-parasitic immunity, IL-13 is critical for goblet cell hyperplasia and mucus production at mucosal sites (1). These responses are particularly essential for the expulsion of gastrointestinal worms from the host (2). However, the same mucus hypersecretion response is a hallmark of pathogenicity in asthmatic patients (3). Similarly, IL-13 can induce cytoprotective cytokines such as vascular endothelial growth factor to protect from acute lung injury (4), yet drive airway smooth muscle cell contraction leading to broncho-constrictive effects during asthma pathogenesis (5). However, IL-13 and IL-4 have overlapping signalling pathways and both utilize IL-4R $\alpha$. IL-4 signals through the type I receptor (IL-4R $\alpha$ paired with the common $\gamma$ chain) and the type II receptor (IL-4R $\alpha$ paired with IL-13R $\alpha 1$ ) whereas IL-13 only signals through the type II receptor. However, IL13 can also ligate IL-13R $\alpha 2$, which serves primarily as a non-signalling decoy receptor but may have signalling functions distinct from $\operatorname{IL}-13 \mathrm{R} \alpha 1(6,7)$. Consequently, disentangling the relative roles of each cytokine in specific cell types has been challenging (8). Whilst IL-13 has been a therapeutic target for asthma with ongoing clinical trials (9), dupilumab, anti-IL4R $\alpha$ which inhibits both IL-4 and IL-13 signalling, has been a front-runner treatment showing efficacy in severe asthma patients (10). Thus, understanding the individual roles of these two cytokines has important clinical implications.

Collagen deposition following tissue injury is an important aspect of wound healing and repair. However, in asthma and other chronic inflammatory conditions, dysregulated extracellular matrix (ECM) remodelling and fibrosis leads to many pathological features of disease, with increased deposition of collagen and basement membrane thickening leading to a significant decline in airway function $(11,12)$. In such disease settings, a pro-fibrotic role for IL-13 is evidenced by its ability to activate pulmonary fibroblasts and stimulate fibrillar 
collagen synthesis (13-16). Further, the role of IL-13 in promoting liver fibrosis, such as

during schistosomiasis and other pathologies, is well-characterised $(6,17,18)$. However, there is an apparent context-dependent role for IL-13 in promoting pulmonary fibrosis. For instance, IL-13 is required for fibrotic changes in the lung following Schistosoma mansoni egg challenge but not in the bleomycin model of pulmonary fibrosis (19). While these studies implicate IL-13 in regulating ECM components such as fibrous collagens during a variety of chronic inflammatory conditions, less is known about how IL-13 may affect the ECM and associated regulators as a whole and in acute contexts of lung injury.

In this study, we examined the function of IL-13 during the early stages of infection with the lung-migrating nematode parasite Nippostrongylus brasiliensis. We found that IL-13 was required for the full induction of airway eosinophilia and for limiting lung injury, independent from the other type 2 cytokines IL-4 and IL-5. IL-13 did not have a major effect on collagen dynamics during the early phase of infection. However, IL-13 was critical for the upregulation of type 2 effector molecules involved in collagen regulation and tissue repair, such as epithelial-derived resistin-like molecule alpha (RELM- $\alpha$ ). Through both proteomic and transcriptomic approaches, we provide new insight into the contribution of IL-13 to pulmonary helminth infections, in particular suggesting a broader role for IL-13 in overall type 2 immunity during acute lung injury. 


\section{Results}

\section{Lung injury and vascular damage is exacerbated in the absence of IL-13} into the circulation and by day 2 post-infection (D2pi) burst through the lung capillaries and the airways causing extensive tissue damage and haemorrhaging (20). To evaluate the role of IL-13 we used Il13 ${ }^{\text {tm3.1Anjm }}$ (IL-13 eGFP knock-in) mice, which are deficient for IL-13 when bred as homozygotes (henceforth referred to as $I l 13^{-/-}$). Following infection of $I l 13^{-/-}$, we

110 assessed acute bleeding as well the cumulative clearance of blood (Figure 1A). We first measured the bronchoalveolar lavage (BAL) fluid absorbance at $540 \mathrm{~nm}$, which correlates with the increased presence of haemoglobin due to bleeding (21). In the absence of IL-13, infected mice had an increased level of airway haemorrhage on D2pi relative to WT mice (Figure 1A). Efferocytosis of red blood cells has been shown to occur in the N. brasiliensis

115 model (22). Therefore, as an additional measure of bleeding, we assessed the accumulated uptake of red blood cells over time by measurement of haemosiderin within airway macrophages. Consistent with exaggerated bleeding, infected $I l 13^{-/-}$mice had increased numbers of haemosiderin-laden macrophages in the lung compared to controls, as determined by Prussian blue staining on D6pi (Figure 1A). To assess airway damage following infection,

120 we evaluated H\&E-stained lung sections with lacunarity analysis to determine gaps in alveolar structures (23). By D2pi, $I l 13^{-/-}$mice had increased lacunarity scores relative to WT (Figure 1B). Upon gross inspection of lung sections from D2pi, it was evident that infected $I l 13^{-/-}$lungs had larger gaps in the alveoli, presumably in areas proximal to where larvae burst through the tissue (Figure 1C). However, by D6pi lacunarity was comparable between $I l 13^{-/-}$and WT mice (Figure 1B). These data strongly suggest an early host tissue-protective role for IL-13 in partially limiting airway haemorrhaging and tissue damage immediately after $N$. brasiliensis entry into the lung. 

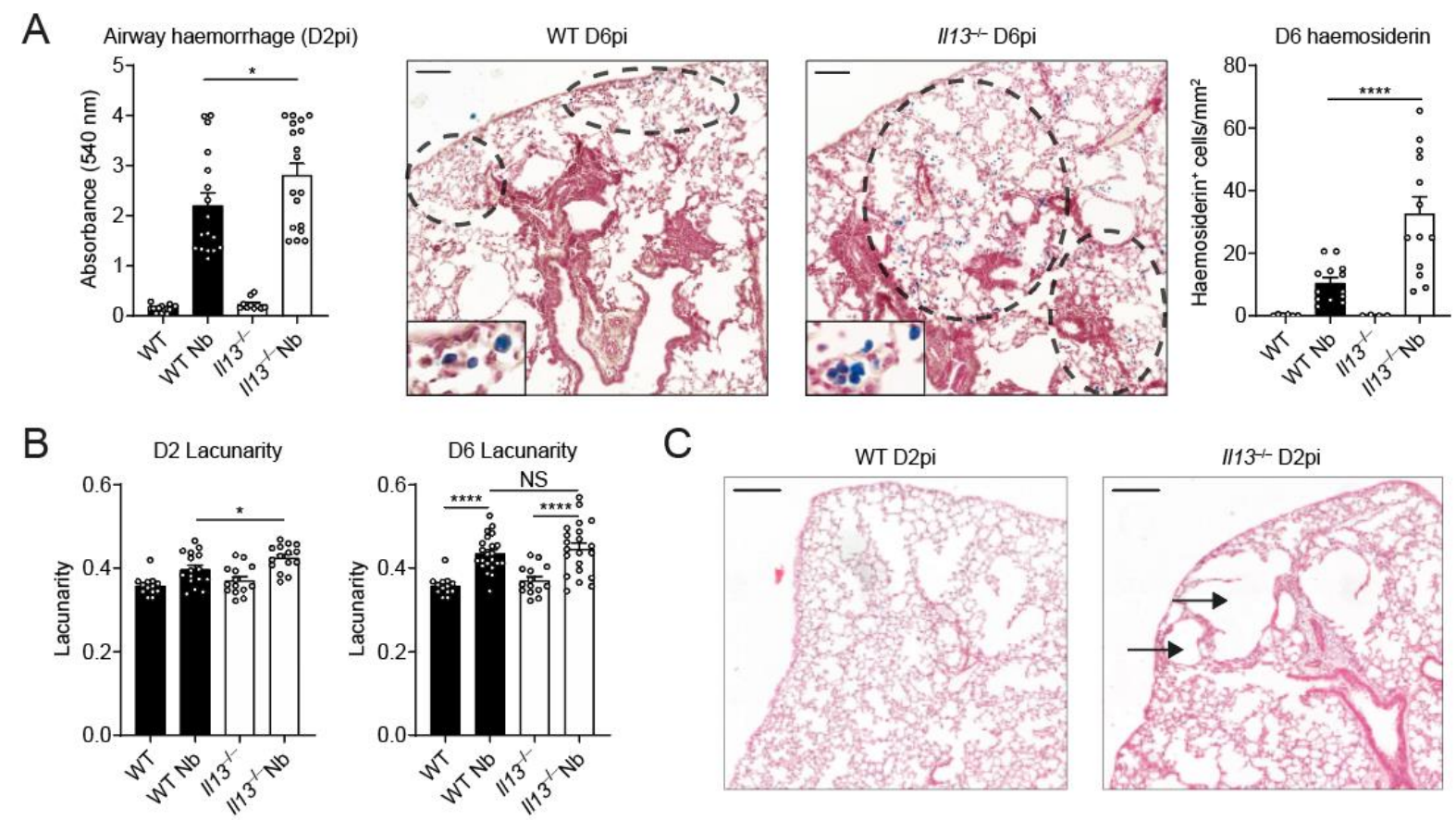

C
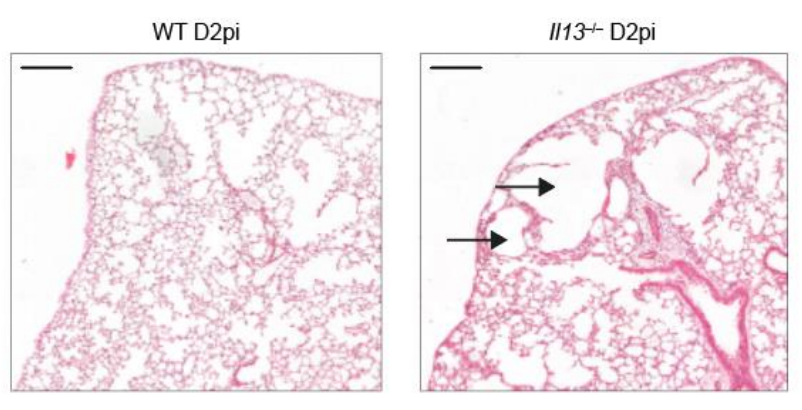

Figure 1 Tissue-protective role for IL-13 during acute lung injury. WT and $I l 13^{-/}$mice were infected with $N$. brasiliensis (Nb). (A) On D2pi, BAL fluid absorbance at $540 \mathrm{~nm}$ was quantified to measure airway haemorrhage. On D6pi, lung lobe sections were stained with Prussian blue and haemosiderin-laden cells (blue) were enumerated per area of tissue (scale bar $=100 \mu \mathrm{m}$ ). (B) To measure airway damage on D2pi and D6pi, lacunarity for whole lung lobes was computed. (C) Representative haematoxylin and eosin images of infected WT and $I l 13^{-/-}$lungs showing alveolar damage in the tissue (scale bar $=200 \mu \mathrm{m}$ ). Data (mean \pm SEM) were pooled from 3 individual experiments with 3-6 mice per group (per experiment). NS not significant, ${ }^{*} P<0.05$, $* * * * P<0.0001$ (one-way ANOVA and Tukey-Kramer post hoc test).

\section{IL-13 is required for airway eosinophilia during $N$. brasiliensis infection}

Neutrophilia is a major contributor to acute lung injury and haemorrhage during

140 helminth infection (24). At D2pi, neutrophils are the predominant infiltrating granulocyte and contribute to worm killing but at the expense of host tissue injury $(24,25)$. We hypothesised that the exacerbated bleeding and damage in $I l 13^{-/-}$mice was due to the requirement for IL13 to suppress the early neutrophilia. Thus, we aimed to characterise the role of IL-13 during the early granulocyte response in the lungs. Using $N$. brasiliensis infection of $I l 13^{-/-}$mice,

145 we found that the proportion of infiltrating neutrophils in the BAL was not significantly altered in the absence of IL-13 when compared to infected WT mice on D2pi (Figure 2A). In terms of absolute numbers, $I l 13^{-/-}$mice only exhibited a slight trend for increased neutrophils compared to controls on D2pi and D4pi (Figure 2B). Between D4-6pi the parasite larvae have exited the lungs, en route to the small intestine and the granulocyte 
bioRxiv preprint doi: https://doi.org/10.1101/2020.10.14.337949; this version posted October 14, 2020. The copyright holder for this preprint (which was not certified by peer review) is the author/funder, who has granted bioRxiv a license to display the preprint in perpetuity. It is made available under aCC-BY-NC-ND 4.0 International license.

response shifts towards eosinophilia in the airways. As early as D4pi, $I l 13^{-/-}$mice had a

major reduction in the proportion and number of eosinophils in the BAL relative to infected WT mice and this response was sustained at D6pi (Figure 2A, 2C). This major reduction in eosinophil proportions in infected $I l 13^{-/-}$mice accounted for the apparent increase in neutrophil percentage at D4pi and D6pi. Together, these results show that IL-13 is required for the full induction of airway eosinophilia following $N$. brasiliensis infection.
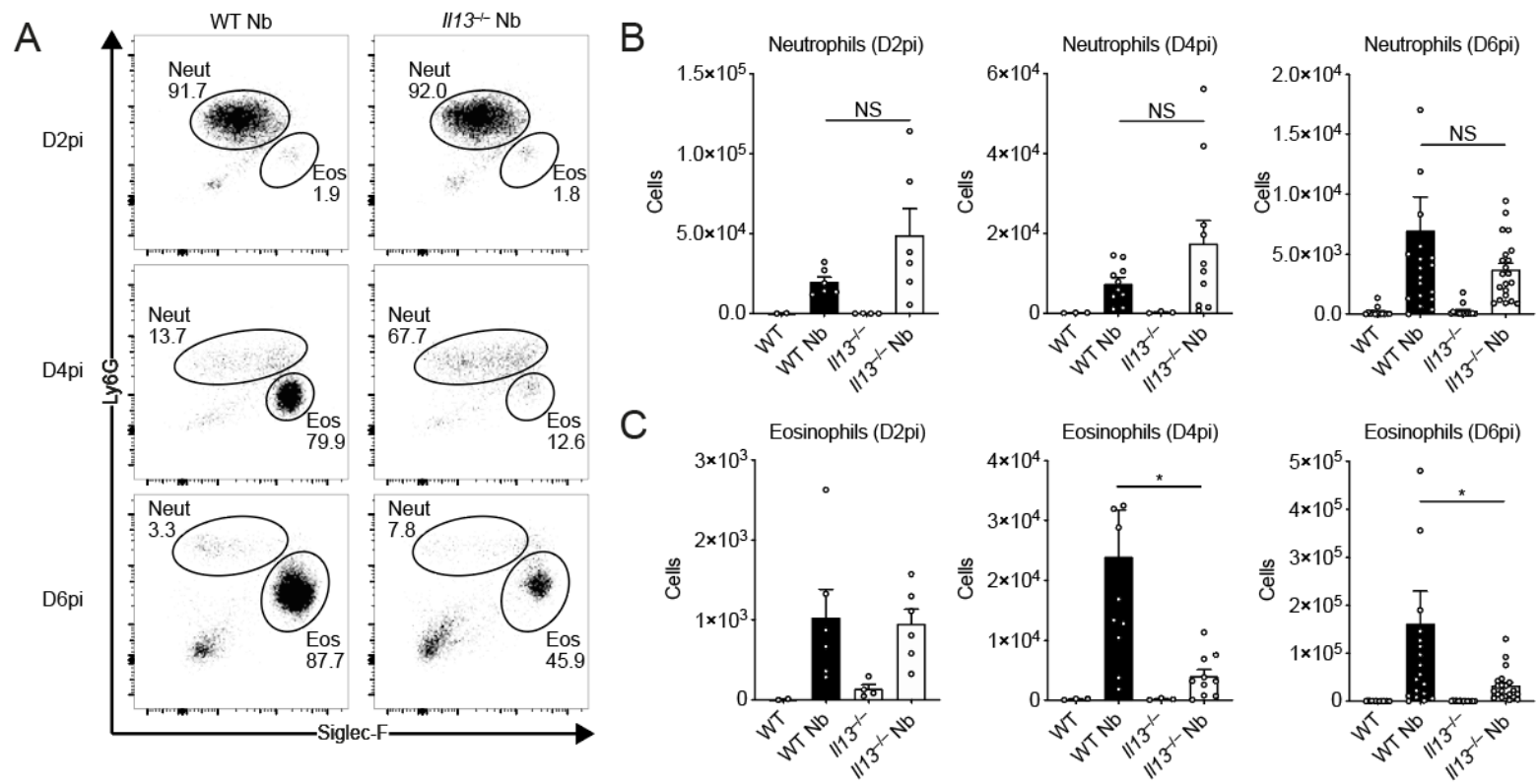

Figure 2 IL-13-dependent airway eosinophilia during $N$. brasiliensis infection. WT and $I l 13^{-/-}$mice were infected with $N$. brasiliensis $(\mathrm{Nb})$ and BAL cells were analysed by flow cytometry. (A) Representative plots of percentages of BAL CD11 ${ }^{-} \mathrm{CD} 11 \mathrm{~b}^{+} \mathrm{Ly}_{6 \mathrm{G}^{+}}$neutrophils and $\mathrm{CD} 11 \mathrm{c}^{-} \mathrm{CD} 11 \mathrm{~b}^{+}$Siglec- $\mathrm{F}^{+}$eosinophils on D2, D4, and D6pi. Numbers indicate percentage of cells within total live CD45.2+ cells. (B) Total BAL neutrophil and (C) eosinophil cell counts on D2, D4, and D6pi. Data (mean \pm SEM) were representative (D2pi) or pooled (D4 and D6pi) from 4 individual experiments with 3-5 mice per group (per experiment). NS not significant, ${ }^{*} P<0.05$ (one-way ANOVA and Tukey-Kramer post hoc test).

\section{IL-4 and IL-5 do not compensate in the absence of IL-13 after $N$. brasiliensis infection}

Previous studies using the $N$. brasiliensis model in IL-4R $\alpha$-deficient animals or IL4/IL-13-double-deficient mice did not distinguish between the relative roles of IL-4 and IL13 during infection (26-28). Unlike those settings, in IL-13 cytokine-deficient mice which

170 have intact type I and II IL-4 receptors, IL-4 may compensate for IL-13-deficiency. To evaluate the potential role of IL-4, we first assessed overall susceptibility to $N$. brasiliensis in 
bioRxiv preprint doi: https://doi.org/10.1101/2020.10.14.337949; this version posted October 14, 2020. The copyright holder for this preprint (which was not certified by peer review) is the author/funder, who has granted bioRxiv a license to display the preprint in perpetuity. It is made available under aCC-BY-NC-ND 4.0 International license.

the small intestine which is known to be dependent on both IL-4R $\alpha$ and IL-13R $\alpha 1$ (i.e. type I and II IL-4 receptors) $(26,29)$. Where WT mice had largely cleared their parasites, all $I l 13^{-/-}$ mice harboured adult intestinal worms on D6pi (Figure 3A). However, IL-13 can play a role in the differentiation of Th2 cells (30) and it was therefore possible that increased worm burden in IL-13 deficient mice was due to impaired Th2 cell activation following infection. We therefore assessed lung $\mathrm{CD}^{+} \mathrm{T}$ cells on D6pi by ex-vivo stimulation and measurement of intracellular type 2 cytokine expression. We confirmed that lung CD4 ${ }^{+} \mathrm{T}$ cells in our $1 l 13^{-/-}$ mouse strain expressed eGFP in lieu of functional IL-13 after infection with $N$. brasiliensis

180 when compared to controls (Figure 3B). Importantly, in the absence of IL-13 expression, neither IL-4 nor IL-5 cytokine expression was changed in $\mathrm{CD}^{+}{ }^{+} \mathrm{T}$ cells following infection (Figure 3C). Furthermore, measurement of type 2 cytokine mRNA from whole lung also showed no change in the expression of Il4 and Il5 between infected $I l l 3^{-/-}$and WT mice (Figure 3D). Thus, IL-13 cytokine-deficient mice become fully susceptible to $N$. brasiliensis 185 infection with no evidence that altered susceptibility is due to reduced IL-4/IL-5 during the adaptive type 2 response.
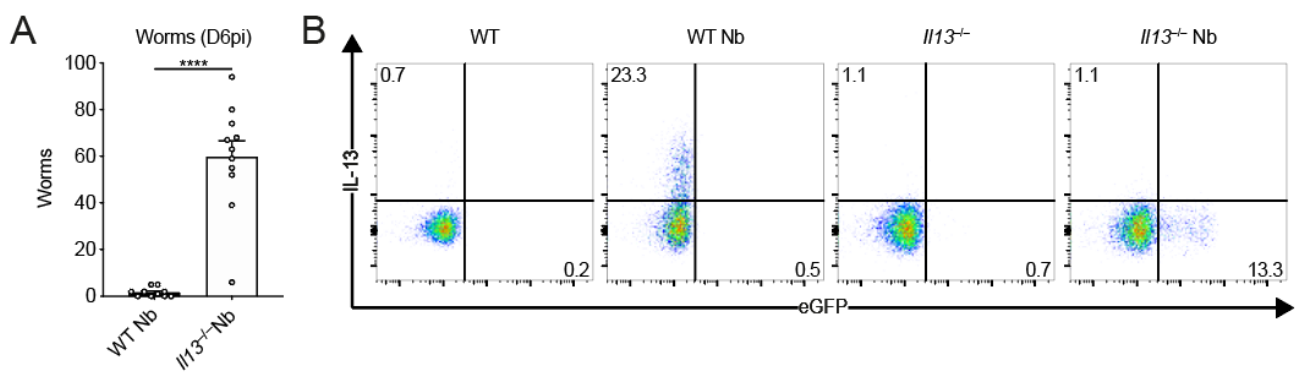

C
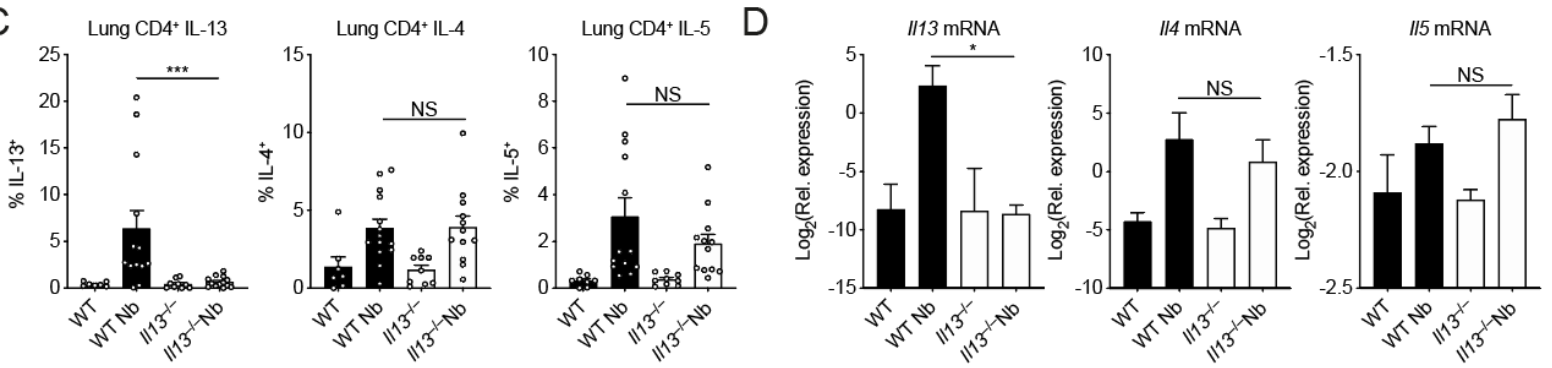

Figure 3 IL-4 and IL-5 do not compensate in the absence of IL-13 during N. brasiliensis infection. WT and

$190 I l 13^{-1-}$ mice were infected with N. brasiliensis (Nb). (A) On D6pi, adult worms in the small intestine were quantified. (B) Representative flow cytometry plots of lung $\mathrm{CD}^{+} \mathrm{T}$ cells stimulated ex vivo to measure 
intracellular WT IL-13 and KO eGFP expression. (C) Percentages of CD4+ ${ }^{+}$cells expressing IL-13, IL-4, and IL-5. (D) Whole lung Il13, Il4, and Il5 mRNA was measured by quantitative real-time PCR (data normalised against housekeeping gene $R p l 13 a$ ). Data (mean \pm SEM) were pooled from 3 individual experiments with 3-5 mice per group (per experiment). NS not significant, $* P<0.05$, $* * * P<0.001$, $* * * * P<0.0001$ (one-way ANOVA and Tukey-Kramer post hoc test).

\section{Lung proteomic analysis following $N$. brasiliensis infection}

Our results thus far showed that IL-13 has a role in limiting lung injury and enabling

changes in lung structure were not evident at day 6 between WT and $I l 13^{-/-}$mice (Figure

1C), it is feasible that changes to physical lung injury in the absence of IL-13, as was seen on D2 post-infection (Figure 1B \& 1C), could have profound effects on the way in which the lung repairs compared to WT animals. To directly address this possibility at the whole tissue level, we performed mass spectrometry on H\&E-stained lung sections at D6pi. In infected WT mice, 648 proteins were significantly changed (adjusted $P$ value $<0.05$ ) relative to uninfected mice with most of these proteins being upregulated (Figure 4A). We then specifically analysed changes in the ECM and matrix-related proteins (defined from the Matrisome Project (31)), performing hierarchical clustering across groups after $N$.

clustered together, with proteins reduced in WT mice after infection, an effect not replicated in $I l 13^{-/-}$mice. Such differences may relate to an already lower level of expression of these collagens under basal conditions in $I l 13^{-/-}$vs. WT mice. Evaluation of the relative abundance of collagen types across groups confirmed dysregulated collagen levels in the absence of IL-

215 13, with $N$. brasiliensis infection altering collagen expression in WT but not $I l 13^{-/-}$mice (Figure 4C). Fibrillar collagens I and III, while already low in $I l 13^{-/-}$mice, were decreased in infected WT mice and basement membrane-associated collagens IV and VI were also dysregulated in $I l 13^{-/-}$mice. To visualise total collagen deposition, Masson's trichrome staining was performed but did not show any major differences between infected WT and 
$220 \quad I l 13^{-/-}$mice at D6pi (Figure S1). Further, hydroxyproline levels were measured as a proxy for total collagen in the lung and confirmed no gross differences between the groups (Figure S1). To gain further insight into global IL-13-dependent changes in the lung, we performed pathway analysis on differentially expressed proteins (by non-adjusted $P$ value $<0.05$ ) comparing infected WT and $I l 13^{-/-}$mice (Figure 4D). IL-13-dependent canonical pathway analysis showed a downregulation (blue) in pathways relating to protein synthesis and cellular stress after infection, with $71 \%$ of endoplasmic reticulum stress pathway-associated proteins being regulated by IL-13. Additionally, mTOR signalling and antigen presentation pathways appeared to be altered in the absence of IL-13. Whilst proteomic analysis of lungs from infected $I l 13^{-/-}$mice did not reveal any differences in matrisome components compared to infected WT mice, RELM- $\alpha$ and surfactant protein D (SP-D), two proteins heavily implicated in type 2 immunity $(32,33)$, were significantly decreased in infected $I l 13^{-/-}$lungs amongst the total proteome (Figure S2). Several other key proteins were found to be significantly downregulated in $I l 13^{-/-}$mice based on relative abundance when compared to infected WT mice including AMCase, BRP39, and Ym1 (Figure 4E) molecules also strongly associated with pulmonary type 2 immunity $(25,34)$. These data suggest that IL-13 may not directly regulate ECM remodelling following acute lung injury on D6pi following $N$. brasiliensis infection. However, IL-13 is critical for the induction of type 2 effector molecules which may determine the subsequent tissue repair responses. 
bioRxiv preprint doi: https://doi.org/10.1101/2020.10.14.337949; this version posted October 14, 2020. The copyright holder for this preprint (which was not certified by peer review) is the author/funder, who has granted bioRxiv a license to display the preprint in perpetuity. It is made available under aCC-BY-NC-ND 4.0 International license.

A

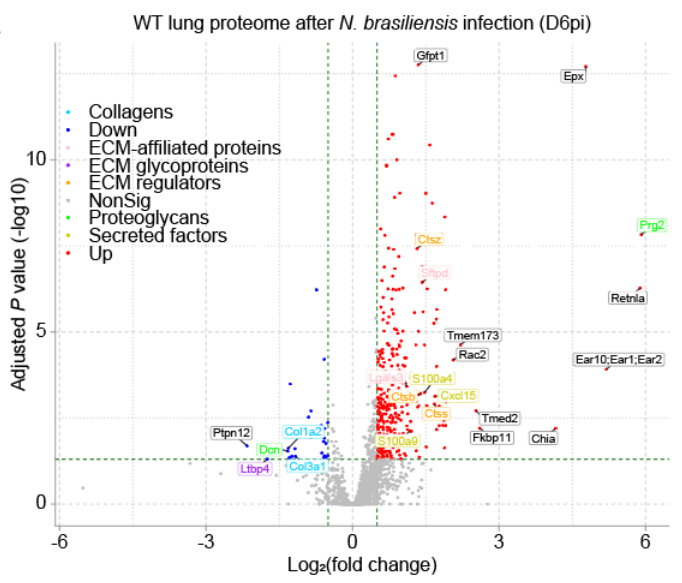

C
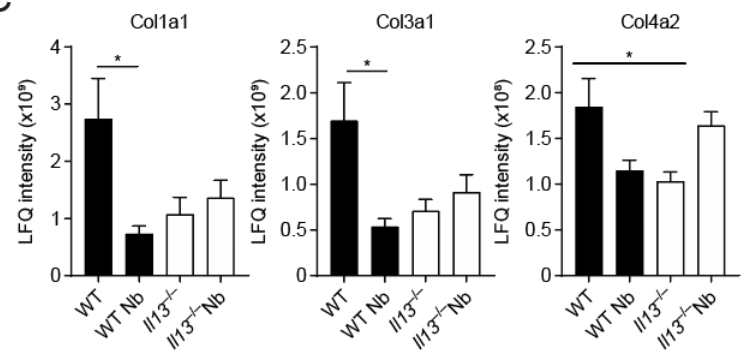

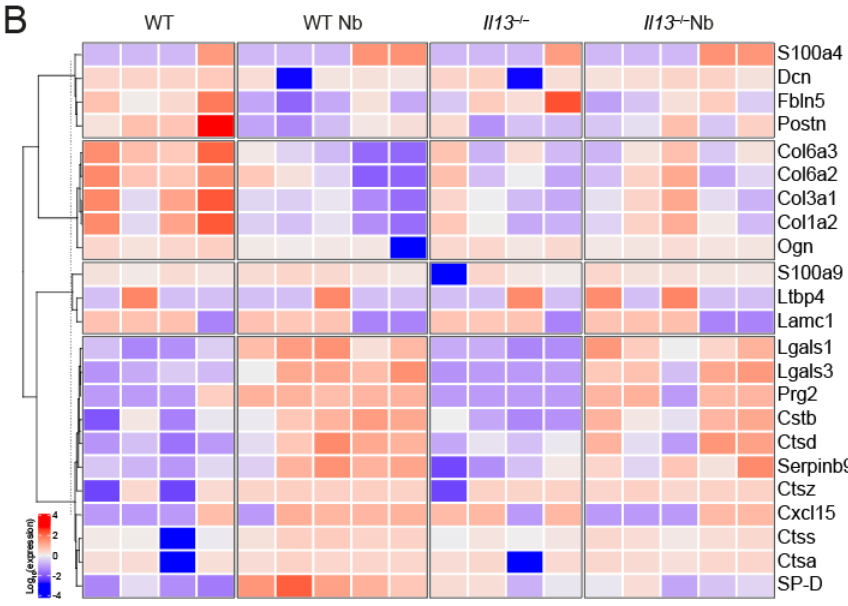

WT

WT Nb $1113^{-1-}$

$1113^{-1-\mathrm{Nb}}$
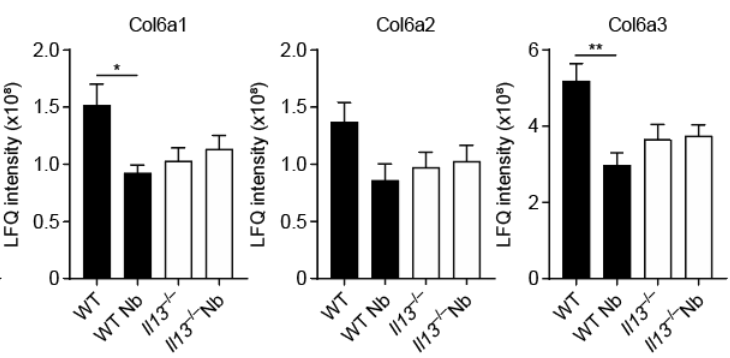

Changes in canonical pathways in $111^{--}$after N. brasiliensis infection (D6pi)

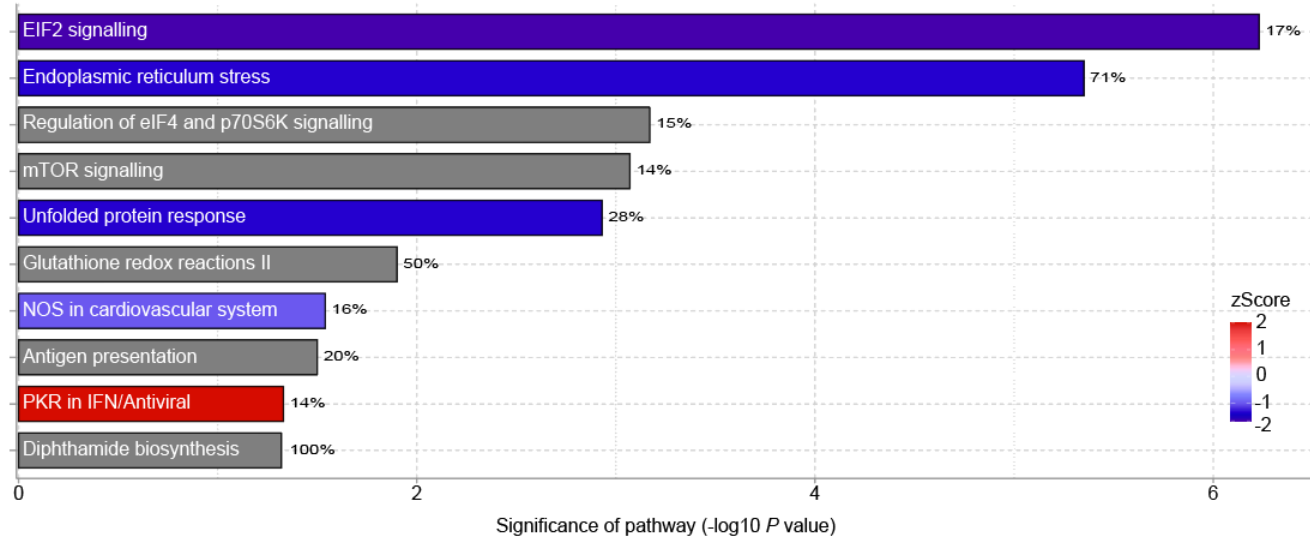

E
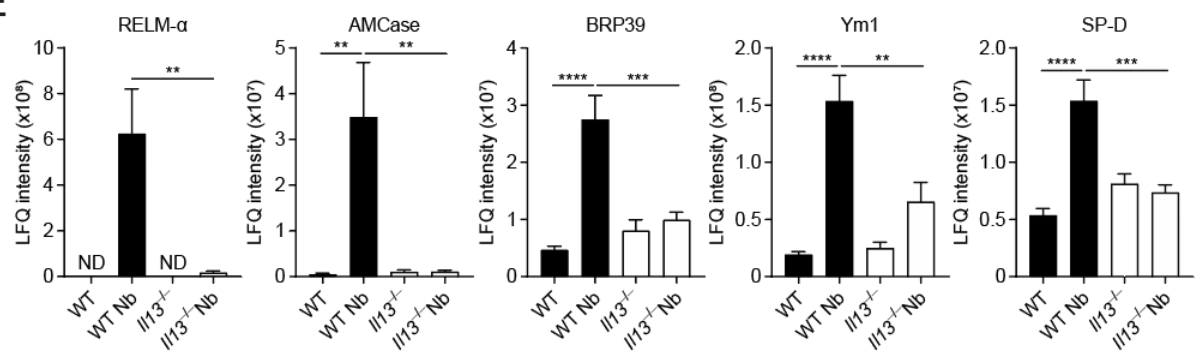

Figure 4 IL-13-dependent lung proteomic changes during $N$. brasiliensis infection. WT and $I l 13^{-/-}$mice were infected with $N$. brasiliensis $(\mathrm{Nb})$ and on D6pi lungs were prepared for proteomic analysis. (A) Volcano plot of infected WT lungs (D6pi) showing differential expression of up- (red) or down- (blue) regulated proteins with matrisome annotations (fold change relative to naïve WT mice). Black labels indicate proteins lacking matrisome annotations. (B) Unsupervised, hierarchically clustered heatmap of expression of matrisome proteins comparing naïve and $\mathrm{Nb}$-infected groups of WT and $I l 13^{-/}$mice on D6pi. Columns in each set represent different (biological repeat) mice in each group (C) Relative abundance (LFQ intensity) of collagen peptides comparing infected WT and $I l 13^{-/-}$lungs on D6pi. (D) Predicted changes in canonical pathways based on changes in the proteome of infected $I l 13^{-/-}$mice compared to infected WT mice (downregulation in blue, upregulation in red, and no specified direction in grey). Percentage indicates the relative number of proteins that are regulated in each pathway. (E) Relative abundance of peptides highly associated with type 2 immunity 
comparing infected WT and $I l 13^{-/-}$lungs on D6pi. Data (mean \pm SEM in $\mathbf{C}$ and E) are pooled from 2 independent mass spectrometry runs with $4-5$ mice per group in total. $* P<0.05$, $* * P<0.01, * * * P<0.001$, $* * * * P<0.0001$ (one-way ANOVA and Tukey-Kramer post hoc test).

\section{IL-13 is required for induction of epithelial cell-derived RELM- $\alpha$}

The proteomic analysis led us to further characterise the contribution of IL-13 to RELM- $\alpha$ expression in the lung. RELM- $\alpha$ is an important type 2-associated effector

260 molecule implicated in repair processes that have been previously described in the skin and lungs $(35,36)$. We measured RELM- $\alpha$ protein in the BAL fluid by ELISA (i.e. release into the airways) and consistent with our proteomics data found decreased RELM- $\alpha$ levels in $I l 13^{-/-}$mice infected with N. brasiliensis relative to infected WT mice (Figure 5A). Similarly, quantification of mRNA in the whole lung showed that the induction of Retnla expression on D4pi and D6pi was reduced in the absence of IL-13 (Figure 5B). In addition, we performed immunofluorescence staining in lung sections and found that the airways, which were highly RELM- $\alpha^{+}$following infection in WT mice, appeared largely diminished in RELM- $\alpha$ expression in infected $I l 13^{-/-}$mice (Figure 5C). To directly quantify this cellular RELM- $\alpha$ expression, lung cell suspensions were analysed by flow cytometry for intracellular RELM- $\alpha$. In the absence of IL-13, CD45-EpCAM ${ }^{+}$epithelial cells had significantly impaired expression of RELM- $\alpha$ as early as D2pi and was still muted by D6pi when compared to WT controls (Figure 5D). Consistent with previous findings $(36,37)$, epithelial cells were the major source of RELM- $\alpha$ at these time points whilst other cellular sources such as alveolar macrophages, neutrophils, and eosinophils, were relatively unchanged in the absence of IL-13 following infection (data not shown). As a complementary experiment, equimolar amounts of systemic IL-4 and IL-13 were each delivered by intraperitoneal injection into WT mice and $18 \mathrm{~h}$ later epithelial RELM- $\alpha$ expression was measured in the lungs. In contrast to IL-4 which had no apparent effect, systemic IL-13 
bioRxiv preprint doi: https://doi.org/10.1101/2020.10.14.337949; this version posted October 14, 2020. The copyright holder for this preprint (which was not certified by peer review) is the author/funder, who has granted bioRxiv a license to display the preprint in perpetuity. It is made available under aCC-BY-NC-ND 4.0 International license.

delivery was able to potently drive RELM- $\alpha$ expression in $\mathrm{CD}^{4} 5^{-} \mathrm{EpCAM}^{+}$epithelial cells

(Figure 5E). However, we hypothesized that the differences in response to comparable doses

of IL-4 vs. IL-13 may be due to bioavailability in the lung when delivered systemically.

Therefore, we directly administered the cytokines to the lung via intranasal instillation and found that both IL-4 and IL-13 induced epithelial cell derived-RELM- $\alpha$ (Figure 5F). Taken together, these results show that IL-13 is both necessary and sufficient to stimulate lung epithelial cell RELM- $\alpha$ and suggest that lung epithelial cells may be more sensitive to IL-13 relative to IL-4.

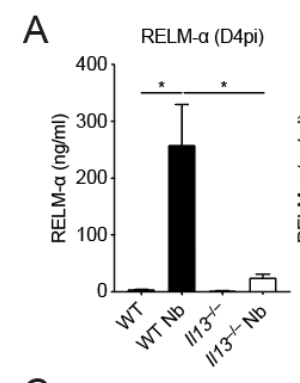

C
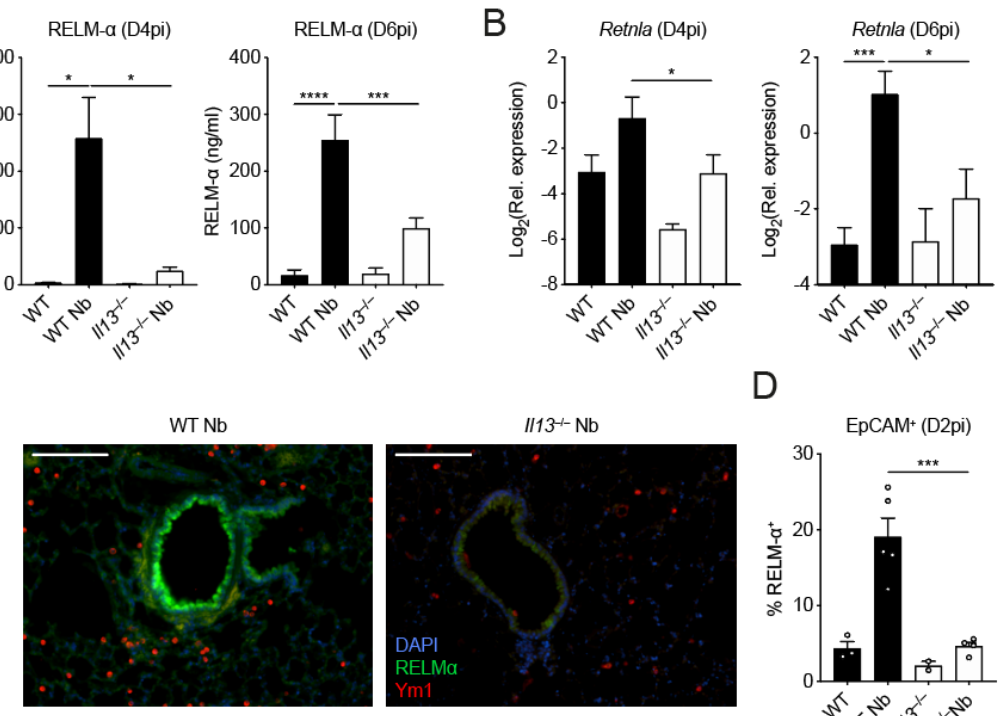

D

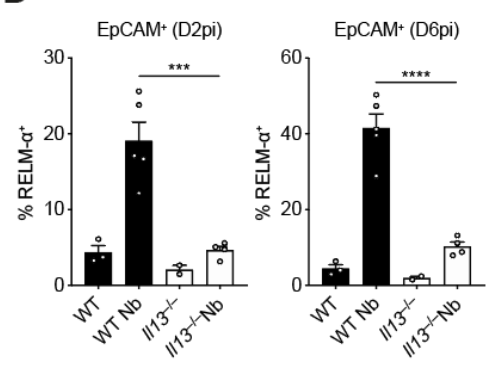

$\mathrm{E}$
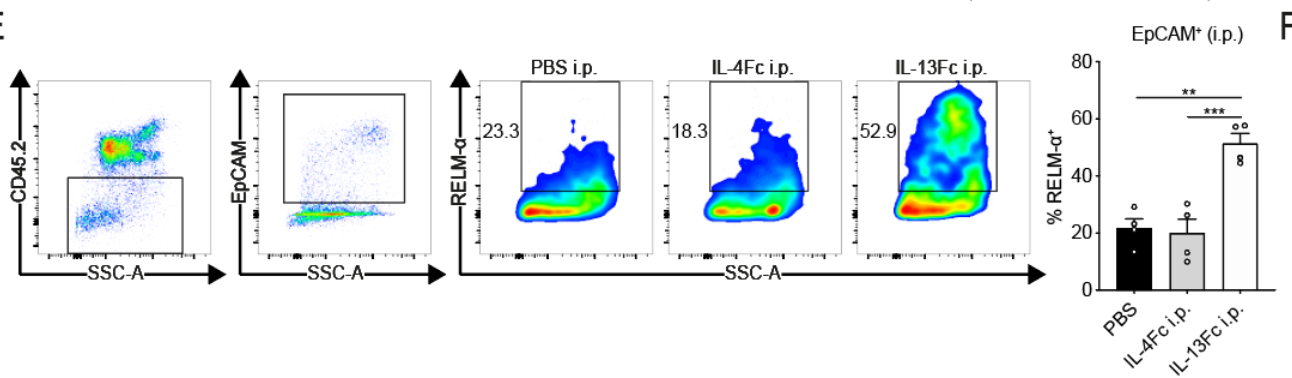

$\mathrm{F}$

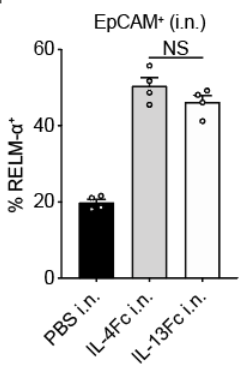

290 Figure 5 Lung epithelial cell expression and airway release of RELM- $\alpha$ is IL-13 dependent. WT and Ill ${ }^{-/-}$ mice were infected with $N$. brasiliensis (Nb). (A) On D4 and D6pi RELM- $\alpha$ protein levels in the BAL fluid were measured by ELISA. (B) D4 and D6pi whole lung Retnla mRNA was measured by quantitative real-time PCR (data normalised against housekeeping gene Rpl13a). (C) Lung RELM- $\alpha$ (green) and Ym1 (red) were imaged by immunofluorescence microscopy (scale bar $=100 \mu \mathrm{m}$ ). (D) On D2 and D6pi, CD45-EpCAM ${ }^{+}$lung epithelial cells were analysed and quantified by flow cytometry to measure intracellular RELM- $\alpha$. (E) WT mice were injected with either PBS, IL-4Fc, or IL-13Fc i.p. or (F) i.n. and $18 \mathrm{~h}$ later, $\mathrm{CD}^{-} 5^{-} \mathrm{EpCAM}^{+}$lung epithelial cell RELM- $\alpha$ expression was measured by flow cytometry. Data (mean \pm SEM) in A-B were pooled from 3 individual experiments with 3-5 mice per group (per experiment). Data (mean \pm SEM) in C-F were 
bioRxiv preprint doi: https://doi.org/10.1101/2020.10.14.337949; this version posted October 14, 2020. The copyright holder for this preprint (which was not certified by peer review) is the author/funder, who has granted bioRxiv a license to display the preprint in perpetuity. It is made available under aCC-BY-NC-ND 4.0 International license.

representative of 2 individual experiments with 2-5 mice per group (per experiment). NS not significant, $* P<0.05, * * P<0.01, * * * P<0.001, * * * * P<0.0001$ (one-way ANOVA and Tukey-Kramer post hoc test).

\section{IL-13 broadly regulates type 2 immunity in the lung during $N$. brasiliensis infection}

Due to the technical limitations of proteomics not being able to detect low molecular weight cytokines and chemokines, we performed transcriptional profiling of lung tissue from N. brasiliensis-infected WT and $I l 13^{-/-}$mice to better define the role of IL-13 during type 2 immunity in acute injury settings and to highlight potential mechanisms/pathways involved. Using the Nanostring Myeloid Innate Immunity v2 panel, we screened for differentially regulated genes across groups on D6pi. Principal component analysis showed distinct separation between groups based on infection status (PC1) and genotype (PC2) (Figure 6A).

310 Genes were grouped by unsupervised hierarchical clustering and differentially expressed genes were represented as a heatmap to identify expression patterns across all groups (Figure 6B). Notably, various signature type 2 genes were downregulated in infected $I l 13^{-/-}$mice such as Chil3/4, Arg1, Il33, Retnla, and the eotaxins (encoded by Ccll1 and Ccl24). Conversely, a cluster of pro-inflammatory genes that included $M m p 8, I l 18$, and $T l r 2$ were

315 upregulated in infected IL-13-deficient mice (Figure 6B). Differentially expressed genes were further characterised using Ingenuity Pathway Analysis to identify potential upstream regulators (Figure 6C). Very few regulators were predicted to be upregulated during IL-13 deficiency but included the airway epithelial cell-associated Foxa2 (38) as well as the adenosine A1 receptor, Adora1. In summary, these data demonstrate a broad role for IL-13 in regulating type 2 immunity and epithelial cell function during acute helminth infection in the lung. 


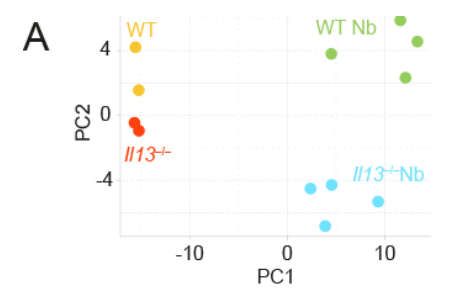

C

Predicted regulators (II13--Nb vs. WT Nb)

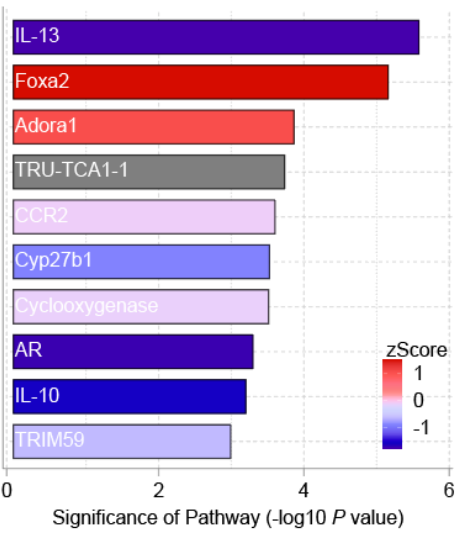

B

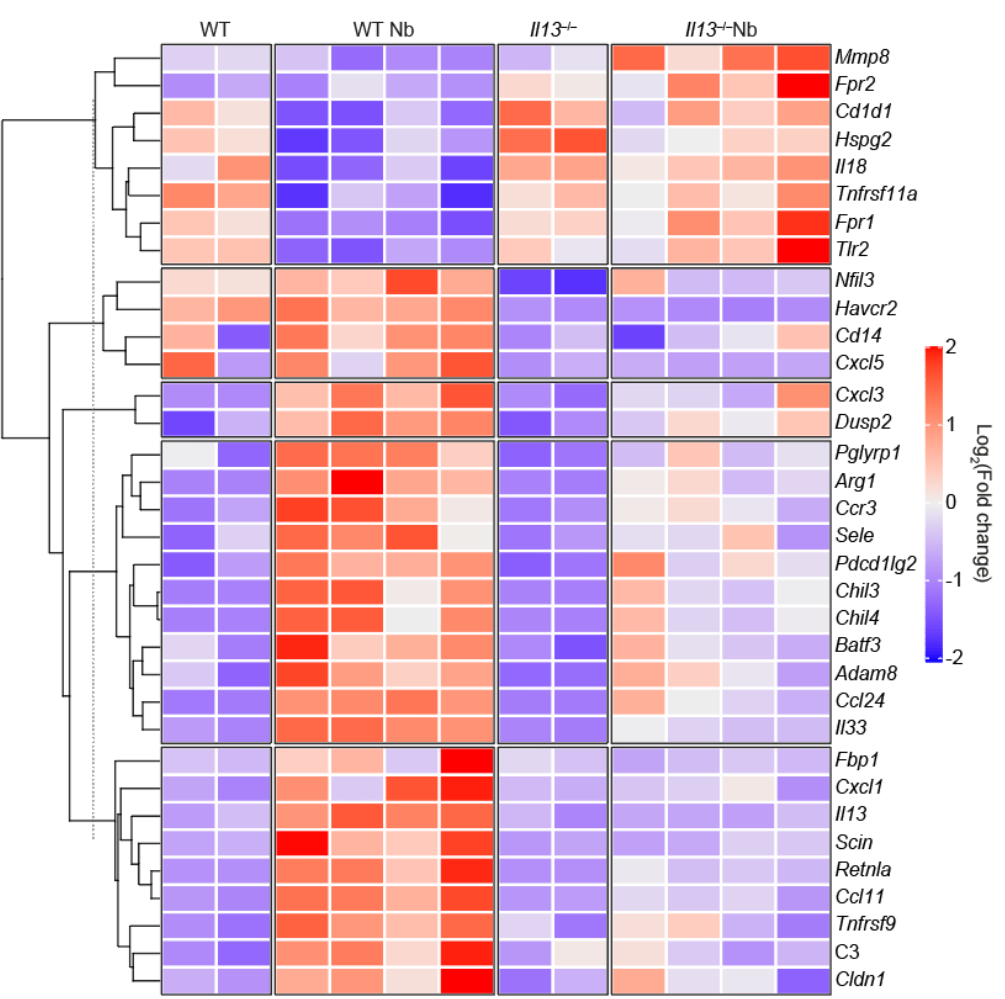

Figure 6 Transcriptional profiling of IL-13-dependent genes in the lung after N. brasiliensis infection. Whole lung RNA from WT and $I l 13^{--}$mice infected with $N$. brasiliensis $(\mathrm{Nb})$ on D6pi was analysed by Nanostring. (A) Principle components (PC) analysis of naïve and infected WT and $I l 13^{-/-}$mice. (B) Unsupervised, hierarchically clustered heatmap of genes differentially expressed between mouse groups with fold change expression level indicated by colour. Columns in each set represent different (biological repeat) mice in each group $(\mathbf{C})$ Predicted upstream regulators from Ingenuity Pathway Analysis. Data are from a single Nanostring run with samples from 2-4 mice per group. 


\section{Discussion}

Despite sharing receptors/signalling components with IL-4, various studies have established a distinct role for IL-13 during type 2 immunity and argued against simple functional redundancy between these two cytokines. For example, IL-4 cytokine-deficient mice, but not IL-4R $\alpha$-deficient mice, are able to expel $N$. brasiliensis from the gut due to intact IL-13 signalling (29). In addition, IL-13-deficient mice fail to clear N. brasiliensis parasites from the gut when compared to IL-4-deficient and WT mice (39). Whilst these studies establish a clear role for IL-13 in mediating type 2 immunity in the small intestine and the establishment of the adaptive immune response, very little is known about the functions of IL-13 in the earlier lung stage of this infection model. Our study reinforces these earlier findings but also reveal a crucial protective role for IL-13 in limiting acute lung injury, promoting airway eosinophilia, and inducing type 2 effector proteins. These lung-specific effects of IL-13 are also consistent with other work showing that pulmonary eosinophilia is impaired in IL-13R $\alpha 1$-deficient mice during asthma (40, 41). lung injury with $N$. brasiliensis. Expression of the type I and type II IL-4 receptors is restricted based on cell type. Hematopoietic cells predominantly express the type I receptor while non-hematopoietic cells such as epithelial cells primarily express the type II receptor (42). While the type II receptor can be ligated by both IL-4 and IL-13, IL-13 can outcompete

350 IL-4 by more efficiently promoting receptor assembly (43). In terms of epithelial cell expression, a model of mechanical injury shows that IL-13R $\alpha 1$ expression increases at the wound edge in cultured alveolar epithelial cells (44). As we observed exacerbated airway injury in $I l 13^{-/-}$mice, it is therefore plausible in our model of nematode-induced lung injury that early alveolar epithelial cell function is dependent on the presence of IL-13. Our study also highlights impaired expression of type 2 effector molecules RELM- $\alpha$ and SP-D by lung 
bioRxiv preprint doi: https://doi.org/10.1101/2020.10.14.337949; this version posted October 14, 2020. The copyright holder for this preprint (which was not certified by peer review) is the author/funder, who has granted bioRxiv a license to display the preprint in perpetuity. It is made available under aCC-BY-NC-ND 4.0 International license.

epithelial cells in the absence of IL-13. RELM- $\alpha$ is an IL-4R $\alpha$-dependent protein involved in lung tissue repair and has been shown to mediate collagen crosslinking via lysl hydroxylase 2 $(32,35)$. Interestingly, SP-D has known roles in promoting immunity to $N$. brasiliensis and is required for the upregulation of RELM- $\alpha$ in the lung (33). Further, our transcriptional

360 profiling predicted a dysregulation of the transcription factor Foxa2 in the absence of IL-13 after infection. Foxa2 is required for alveolarization and negatively regulates goblet cell hyperplasia (38). In terms of type 2 function, the predicted increased Foxa2 activity in $I l 13^{-/-}$ mice is consistent with previous studies showing that IL-13 decreases Foxa2 expression to enable mucin production by airway epithelial cells (45-47). We therefore hypothesize a

365 mechanism of IL-13-mediated suppression of Foxa2 in alveolar epithelial cells that enables the expression and release of type 2 effector molecules such as RELM- $\alpha$. It is also notable that MMP-8 and IL-18 were upregulated in infected $I l 13^{-/-}$mice. MMP-8 and IL-18 are proinflammatory markers associated with chronic obstructive pulmonary disease (COPD) (48, 49). As $N$. brasiliensis infection eventually results in emphysema (22) that resemble features 370 of COPD, our data thus suggest a complex role for IL-13 in the development emphysema. Given the attribution of IL-13 to tissue remodelling and fibrosis in a variety of contexts, we anticipated changes to the matrisome in our acute lung injury model using proteomic analysis. While we saw many changes to the lung matrisome due to infection in WT mice, we did not observe major changes in lung collagens in $I l 13^{-/-}$mice after infection.

375 However, we saw that some major collagens (especially collagen I and III) were reduced in abundance following infection of WT mice. This reduction in the expression of these collagens did not occur in $I l 13^{-/-}$mice, which already had a baseline decrease in these collagens. It is thus possible that IL-13 has a developmental role in collagen organisation that predisposed the $I l 13^{-/-}$mice to enhanced tissue injury. A limitation of our matrisome analysis 380 is that we did not account for potential changes in the localisation of specific collagen types 
and cannot exclude a role for glycosylation state or other post-translational modifications. Additionally, the precise timing of changes in the IL-13-dependent proteome are to be resolved since we observed both early (D2pi) and late (D6pi) effects in our model. Nevertheless, our observation that $I l 13^{-/-}$mice had enhanced haemorrhaging lead us to hypothesize that there may be compromised endothelial cell integrity (e.g. with respect to basement membrane collagen composition) during lung injury in the absence of IL-13. To the best of our knowledge, no prior study has shown a direct protective effect of IL-13 in mitigating airway haemorrhage, which warrants further investigation mechanistically. Additionally, pathway analyses of the proteomic data predicted a dysregulation in protein synthesis and cellular stress pathways (presumably in epithelial cells) upon acute tissue injury in the absence of IL-13, which will be the subject of future studies.

In conclusion, our study has demonstrated a pivotal role for IL-13 in limiting tissue injury and airway bleeding and suggest broader functions for IL-13 in regulating type 2 immunity, in the context of acute lung damage. 


\section{Materials and Methods}

\section{Mice and ethics statements}

WT C57BL/6J were purchased from Charles River UK. Ill $3^{\text {tm } 3.1 \text { Anjm }}$ (50) were maintained on a C57BL/6J background and bred in-house at the University of Manchester. Most

400 experiments had a combination of purchased WT mice and littermate controls. Female and male mice were used at age 8-14 weeks old. Animals were housed in individually ventilated cages with food and water provided ad libitum. Experimental mice were randomly assigned to groups. All experiments were carried out in accordance with the United Kingdom Animals (Scientific Procedures) Act 1986 and under a Project License (70/8548) granted by the Home

405 Office and approved by local Animal Ethics Review Group at the University of Manchester.

\section{N. brasiliensis infection}

N. brasiliensis worms were propagated as previously described (51). Infective L3 larvae were isolated and mice were injected with 250 L3s subcutaneously. Mice were culled by overdose 410 of pentobarbitone i.p. and BAL was performed with 10\% FBS in PBS and lung lobes were collected. Perfusion was not performed due to the compromised lung vasculature during $N$. brasiliensis infection. On D2pi, BAL fluid absorbance was measured at $540 \mathrm{~nm}$ using a VersaMax microplate reader (Molecular Devices) to assess airway haemorrhage. Lung lobes were either stored in RNAlater (Thermofisher), fixed in 10\% neutral-buffered formalin for

415 histology or minced and digested with Liberase TL (Roche) for $30 \mathrm{~min}$ at $37{ }^{\circ} \mathrm{C}$ for analysis of lung epithelial cells by flow cytometry and ex vivo stimulation of lung T cells using cell stimulation cocktail (plus protein transport inhibitors) (eBioscience). On D6pi, adult small intestinal worms were counted using a dissecting microscope following incubation of the small intestine at $37{ }^{\circ} \mathrm{C}$ to collect live adult worms that migrate out of the tissue. 


\section{Flow cytometry}

Single cell suspensions were washed in PBS and Live/Dead staining (Thermofisher) was performed. Samples were Fc-blocked using $\alpha$-CD16/32 (2.4G2) (BD Biosciences) and mouse serum (BioRad). Blocking and subsequent surface staining was performed using PBS containing 2 mM EDTA, 2\% FBS, and $0.05 \% \mathrm{NaN}_{3}$. Antibodies used for staining are listed in Table 1. Following surface staining, cells were incubated with IC fixation buffer (ThermoFisher) prior to permeabilization for intracellular staining. For secondary detection of Ym1 and RELM- $\alpha$, Zenon goat and rabbit antibody labels (ThermoFisher) were used. For RELM- $\alpha$ intracellular staining, cells were directly stained without stimulation or protein

430 transport inhibition. Lung CD4+ T cells were stimulated ex vivo with cell stimulation cocktail containing protein transport inhibitors (ThermoFisher) for $4 \mathrm{~h}$ at $37^{\circ} \mathrm{C}$ prior to staining. For cell quantification, some samples were spiked with $10 \mu \mathrm{m}$ polystyrene beads (Sigma-Aldrich) prior to acquisition. Data were acquired on a BD LSRFortessa flow cytometer and analysed using FlowJo v10 software.

Table 1 List of flow cytometry antibodies used.

\begin{tabular}{lll}
\hline Antigen & Clone & Manufacturer \\
\hline CD45.2 & 104 & BioLegend \\
CD11b & M1/70 & BioLegend \\
CD11c & N418 & BioLegend \\
Ly6C & HK1.4 & BioLegend \\
Ly6G & 1 A8 & BD Biosciences \\
Siglec-F & E50-2440 & BD Biosciences \\
TCR $\beta$ & H57-597 & BioLegend \\
CD3 $\varepsilon$ & 17 A2 & ThermoFisher \\
CD4 & GK1.5 & BioLegend \\
CD8 & $53-6.7$ & BioLegend \\
CD19 & 6 D5 & BioLegend \\
B220 & RA3-6B2 & ThermoFisher \\
EpCAM & 9 C4 & BioLegend \\
CD31 & 390 & BioLegend \\
IL-4 & 11B11 & BioLegend \\
IL-5 & TRFK5 & BioLegend \\
IL-13 & eBio13A & ThermoFisher \\
RELM- $\alpha$ & Polyclonal & Peprotech \\
\hline
\end{tabular}




\section{RNA extraction and quantitative real-time PCR}

Tissue samples stored in RNAlater (Thermo Fisher Scientific) were processed for RNA extraction using a TissueLyser II and QIAzol reagent (Qiagen). Isolated RNA was quantified 440 using a Qubit fluorimeter and RNA BR kit (Qiagen). cDNA was synthesized using Tetro reverse transcription kit (Bioline) and oligo dT 15-mers (Integrated DNA Technologies). Quantitative real-time PCR was performed using SYBR green mix (Agilent Technologies) and a LightCycler 480 II (Roche). A list of primer sequences used are shown in Table 2. Gene expression levels were determined by second derivative maxima using standard curves 445 (LightCycler software) and expressed relative to the housekeeping gene Rpll3a.

Table 2 List of primer sequences used.

\begin{tabular}{ll}
\hline Primer & Sequence (5'-3') \\
\hline Il4 forward & GAGAGATCATCGGCATTTTGA \\
$I l 4$ reverse & TCTGTGGTGTTCTTCGTTGC \\
$I l 5$ forward & ACATTGACCGCCAAAAAGAG \\
$I l 5$ reverse & CACCATGGAGCAGCTCAG \\
$I l 13$ forward & CCTCTGACCCTTAAGGAGCTTAT \\
$I l 13$ reverse & CGTTGCACAGGGGAGTCT \\
Retnla forward & TATGAACAGATGGGCCTCCT \\
Retnla reverse & GGCAGTTGCAAGTATCTCCAC \\
Rpll3a forward & CATGAGGTCGGGTGGAAGTA \\
Rpll3a reverse & GCCTGTTTCCGTAACCTCAA \\
\hline
\end{tabular}

\section{Lung proteomic analysis}

450 Samples from slides containing whole lung tissue sections were scraped excluding major blood vessels and processed as previously described (52). Peptides were evaluated by liquid chromatography coupled tandem mass spectrometry using an UltiMate ${ }^{\circledR} 3000$ Rapid Separation LC system (Dionex Corporation) coupled to a Q Exactive HF mass spectrometer (ThermoFisher). Raw spectra were aligned using MAXQuant software v1.6.17.0 (53) with the variable modifications of proline and methionine oxidation in addition to "matched between runs" being enabled. Raw data was then imported into R for differential analysis with MSqRob (54) using the default pipeline. Heatmaps were plotted using scaled log10- 
bioRxiv preprint doi: https://doi.org/10.1101/2020.10.14.337949; this version posted October 14, 2020. The copyright holder for this preprint (which was not certified by peer review) is the author/funder, who has granted bioRxiv a license to display the preprint in perpetuity. It is made available under aCC-BY-NC-ND 4.0 International license.

transformed LFQ counts. The mass spectrometry proteomics data have been deposited to the ProteomeXchange Consortium via the PRIDE (55) partner repository with the dataset identifier PXD021853.

\section{Hydroxyproline assay}

Hydroxyproline assay was performed as previously described (56). Whole lungs were incubated overnight in $6 \mathrm{M} \mathrm{HCl}$, in screw-top tubes at $100{ }^{\circ} \mathrm{C}$ covered with aluminium foil. Tubes were cooled to RT and centrifuged at 12,000 x g for 3 min. Hydroxyproline standards were prepared (starting at $0.25 \mathrm{mg} / \mathrm{ml}$ ) and serially diluted with $6 \mathrm{M} \mathrm{HCl}$. Samples and standards $(50 \mu \mathrm{l})$ were transferred into Eppendorf tubes and $450 \mu 1$ chloramine T reagent (55.79 mM chloramine $\mathrm{T}$ (initially dissolved in 50\% N-propanol) in acetate citrate buffer $0.88 \mathrm{M}$ sodium acetate trihydrate, $294 \mathrm{mM}$ citric acid, $1.2 \%$ glacial acetic acid, $0.85 \mathrm{M}$ sodium hydroxide - adjusted to $\mathrm{pH} 6.5$; reagents from Sigma) was added to each tube and incubated at RT for 25 min. Ehrlich's reagent (500 $\mu$ l; $1 \mathrm{M}$ 4-dimethylaminobenzaldehyde in N-propanol:perchloric acid (2:1), Sigma) was added to each tube and incubated at $65{ }^{\circ} \mathrm{C}$ for $10 \mathrm{~min}$ and absorbance at $558 \mathrm{~nm}$ was measured.

\section{Histological and immunofluorescence staining}

Whole left lung lobes were paraffin embedded and $5 \mu \mathrm{m}$ sections were prepared for haematoxylin/eosin or Masson's Trichrome staining. For visualisation of haemosiderin deposits, lung sections were rehydrated and stained with a solution of $5 \%$ potassium ferrocyanide with $10 \% \mathrm{HCl}$ (Prussian blue) for $20 \mathrm{~min}$; sections were then rinsed with $\mathrm{dH} 2 \mathrm{O}$ and counterstained with a solution of $1 \%$ neutral red and $1 \%$ acetic acid for 5 min before being rinsed with $\mathrm{dH} 2 \mathrm{O}$ and dehydrated for mounting. Brightfield images were captured using an Olympus slide scanner and analysed using CaseViewer software (3DHISTECH). 
For immunofluorescence staining, lung sections were rehydrated and subjected to heatmediated antigen retrieval using citrate buffer $(10 \mathrm{mM}$ sodium citrate, $0.05 \%$ Tween-20, $\mathrm{pH}$ 6.0) followed by primary antibody incubation overnight at $4{ }^{\circ} \mathrm{C}$ using biotin-anti-Ym1 and anti-RELM- $\alpha$ (Table 1); sections were then incubated with anti-rabbit FITC (Invitrogen) and streptavidin NL-557 (R\&D systems) for 30 min RT before being mounting using Fluoromount-G containing DAPI (SouthernBiotech). Fluorescent slides were imaged using an EVOS ${ }^{\text {TM }}$ FL Imaging System (ThermoFisher) and analysed using ImageJ.

\section{Lung lacunarity analysis}

Slide-scanned images of H\&E-stained lung lobes were processed in a KNIME software workflow to obtain 50 random regions of interests (ROIs) across the whole lung section. ROIs that contained lobe boundaries or extensive artefacts were excluded from the analysis.

495 The ROIs were then converted to binary images and lacunarity was quantified using the FracLac plugin for ImageJ (default settings). Lacunarity values of all the ROIs were averaged to obtain estimates for the entire lobe.

\section{ELISA}

500 BAL supernatants were analysed for RELM- $\alpha$ using commercially available ELISA kits (Peprotech). Analytes were detected using horse radish peroxidase-conjugated streptavidin and TMB substrate (BioLegend) and stopped with $1 \mathrm{M} \mathrm{HCl}$. Final absorbance at $450 \mathrm{~nm}$ was measured using a VersaMax microplate reader (Molecular Devices).

\section{IL-4-Fc and IL-13-Fc injections}

To extend the half-life of IL-4 and IL-13, fusion proteins were generated of mouse IL-4 and IL-13 with the Fc portion of IgG1 (custom order with Absolute Antibody). Mice were 
bioRxiv preprint doi: https://doi.org/10.1101/2020.10.14.337949; this version posted October 14, 2020. The copyright holder for this preprint (which was not certified by peer review) is the author/funder, who has granted bioRxiv a license to display the preprint in perpetuity. It is made available under aCC-BY-NC-ND 4.0 International license.

injected intraperitoneally with either PBS, $10 \mu \mathrm{g}$ IL-4-Fc, or $10 \mu \mathrm{g}$ IL-13-Fc in $100 \mu \mathrm{l}$ PBS. In other experiments, mice were anaesthetised using isoflurane inhalation and intranasally

510 instilled with either PBS, $10 \mu \mathrm{g}$ IL-4-Fc, or $10 \mu \mathrm{g}$ IL-13-Fc in $40 \mu \mathrm{l}$ PBS. The following day at $18 \mathrm{~h}$ post-treatment, mice were culled for lung cell analysis by flow cytometry.

\section{Nanostring analysis}

Quality control was performed on RNA samples with an Agilent 2200 TapeStation system

515 prior to downstream analyses. Samples were diluted and $100 \mathrm{ng}$ of RNA was processed for running on a Nanostring nCounter® FLEX system using the Myeloid Innate Immunity v2 panel. Raw count data was imported into $\mathrm{R}$ for analysis using the limma package (57). Internal housekeeping and negative control probes were used to ensure data integrity and set thresholds for minimum expression. Data was normalised using the edgeR package (58) and

520 then differential expression was calculated using the limma package. Figures were generated in R using ggplot and the complexheatmap package. Heatmaps were plotted using scaled normalised counts.

\section{Statistical analyses}

525 Graphpad Prism 8 software was used for all statistical analyses. Data were assessed to be normally distributed by the D'Agostino-Pearson omnibus normality test. Differences between experimental groups were assessed by ANOVA (for normally distributed data) followed by Tukey-Kramer post hoc multiple comparisons test or an unpaired two-tailed Student's $t$ test. In cases where data were not normally distributed, a Kruskal-Wallis test was used. For gene expression data, values were $\log _{2}$ transformed to achieve normal distribution. Comparisons with a $P$ value of less than 0.05 were considered to be statistically significant. 


\section{Acknowledgements}

This work was supported by the Wellcome Trust (203128/Z/16/Z, 110126/Z/15/Z and

supported by Medical Research Foundation UK joint funding with Asthma UK (MRFAUK-

2015-302). We thank Andrew McKenzie (Cambridge) for providing the $I l 13^{\text {tm } 3.1 \text { Anjm }}$ mice.

We further thank the Flow Cytometry, Bioimaging, Genomic Technologies, BioMS and

Biological Services core facilities at the University of Manchester.

540

\section{Disclosure}

The authors declare no competing interests. 


\section{References}

545 1. Finkelman, F. D., T. Shea-Donohue, S. C. Morris, L. Gildea, R. Strait, K. B. Madden, L. Schopf, and J. F. Urban. 2004. Interleukin-4- and interleukin-13-mediated host protection against intestinal nematode parasites. Immunol. Rev. 201: 139-155.

2. Shimokawa, C., T. Kanaya, M. Hachisuka, K. Ishiwata, H. Hisaeda, Y. Kurashima, H. Kiyono, T. Yoshimoto, T. Kaisho, and H. Ohno. 2017. Mast cells are crucial for induction of group 2 innate lymphoid cells and clearance of helminth infections. Immunity 46: 863-874.e4. 3. Evans, C. M., K. Kim, M. J. Tuvim, and B. F. Dickey. 2009. Mucus hypersecretion in asthma: causes and effects. Curr. Opin. Pulm. Med. 15: 4-11.

4. Corne, J., G. Chupp, C. G. Lee, R. J. Homer, Z. Zhu, Q. Chen, B. Ma, Y. Du, F. Roux, J. McArdle, A. B. Waxman, and J. A. Elias. 2000. IL-13 stimulates vascular endothelial cell 555 growth factor and protects against hyperoxic acute lung injury. J. Clin. Invest. 106: 783-791. 5. Risse, P. A., T. Jo, F. Suarez, N. Hirota, B. Tolloczko, P. Ferraro, P. Grutter, and J. G. Martin. 2011. Interleukin-13 inhibits proliferation and enhances contractility of human airway smooth muscle cells without change in contractile phenotype. Am. J. Physiol. - Lung Cell. Mol. Physiol. 300: L958-66.

560 6. Gieseck, R. L., M. S. Wilson, and T. A. Wynn. 2018. Type 2 immunity in tissue repair and fibrosis. Nat. Rev. Immunol. 18: 62-76.

7. Karmele, E. P., T. S. Pasricha, T. R. Ramalingam, R. W. Thompson, R. L. Gieseck, K. J. Knilans, M. Hegen, M. Farmer, F. Jin, A. Kleinman, D. A. Hinds, T. Almeida Pereira, R. de Queiroz Prado, N. Bing, L. Tchistiakova, M. T. Kasaian, T. A. Wynn, and K. M. Vannella. 2019. Anti-IL-13R $\alpha 2$ therapy promotes recovery in a murine model of inflammatory bowel disease. Mucosal Immunol. 12: 1174-1186.

8. Wills-Karp, M., and F. D. Finkelman. 2008. Untangling the complex web of IL-4- and IL13-mediated signaling pathways. Sci. Signal. 1: pe55.

9. Bagnasco, D., M. Ferrando, G. Varricchi, G. Passalacqua, and G. W. Canonica. 2016. A critical evaluation of Anti-IL-13 and Anti-IL-4 strategies in severe asthma. Int. Arch. Allergy Immunol. 170: 122-131.

10. Castro, M., J. Corren, I. D. Pavord, J. Maspero, S. Wenzel, K. F. Rabe, W. W. Busse, L. Ford, L. Sher, J. M. FitzGerald, C. Katelaris, Y. Tohda, B. Zhang, H. Staudinger, G. Pirozzi, N. Amin, M. Ruddy, B. Akinlade, A. Khan, J. Chao, R. Martincova, N. M. H. Graham, J. D. 
efficacy and safety in moderate-to-severe uncontrolled asthma. N. Engl. J. Med. 378: 24862496.

11. Elias, J. A., Z. Zhu, G. Chupp, and R. J. Homer. 1999. Airway remodeling in asthma. J. Clin. Invest. 104: 1001-1006.

580 12. Wynn, T. A. 2008. Cellular and molecular mechanisms of fibrosis. J. Pathol. 214: 199210.

13. Doucet, C., D. Brouty-Boyé, C. Pottin-Clémenceau, G. W. Canonica, C. Jasmin, and B. Azzarone. 1998. Interleukin (IL) 4 and IL-13 act on human lung fibroblasts. Implication in asthma. J. Clin. Invest. 101: 2129-2139.

585 14. Kolodsick, J. E., G. B. Toews, C. Jakubzick, C. Hogaboam, T. A. Moore, A. McKenzie, C. A. Wilke, C. J. Chrisman, and B. B. Moore. 2004. Protection from Fluorescein Isothiocyanate-Induced Fibrosis in IL-13-Deficient, but Not IL-4-Deficient, Mice Results from Impaired Collagen Synthesis by Fibroblasts. J. Immunol. 172: 4068-4076. 15. Chun Geun Lee, R. J. Homer, Z. Zhu, S. Lanone, X. Wang, V. Koteliansky, J. M.

590 Shipley, P. Gotwals, P. Noble, Q. Chen, R. M. Senior, and J. A. Elias. 2001. Interleukin-13 induces tissue fibrosis by selectively stimulating and activating transforming growth factor ß1. J. Exp. Med. 194: 809-821.

16. Chung, S. I., J. A. Horton, T. R. Ramalingam, A. O. White, E. J. Chung, K. E. Hudak, B. T. Scroggins, J. R. Arron, T. A. Wynn, and D. E. Citrin. 2016. IL-13 is a therapeutic target in 595 radiation lung injury. Sci. Rep. 6: 39714.

17. Kaviratne, M., M. Hesse, M. Leusink, A. W. Cheever, S. J. Davies, J. H. McKerrow, L. M. Wakefield, J. J. Letterio, and T. A. Wynn. 2004. IL-13 activates a mechanism of tissue fibrosis that is completely TGF- $\beta$ independent. J. Immunol. 173: 4020-4029.

18. Gieseck, R. L., T. R. Ramalingam, K. M. Hart, K. M. Vannella, D. A. Cantu, W. Y. Lu, 600 S. Ferreira-González, S. J. Forbes, L. Vallier, and T. A. Wynn. 2016. Interleukin-13 activates distinct cellular pathways leading to ductular reaction, steatosis, and fibrosis. Immunity 45: $145-158$.

19. Wilson, M. S., S. K. Madala, T. R. Ramalingam, B. R. Gochuico, I. O. Rosas, A. W. Cheever, and T. A. Wynn. 2010. Bleomycin and IL-1 $\beta$-mediated pulmonary fibrosis is IL605 17A dependent. J. Exp. Med. 207: 535-552.

20. Reece, J. J., M. C. Siracusa, and A. L. Scott. 2006. Innate immune responses to lungstage helminth infection induce alternatively activated alveolar macrophages. Infect. Immun. 74: 4970-4981.

21. Meng, F., and A. I. Alayash. 2017. Determination of extinction coefficients of human 
hemoglobin in various redox states. Anal. Biochem. 521: 11-19.

22. Marsland, B. J., M. Kurrer, R. Reissmann, N. L. Harris, and M. Kopf. 2008.

Nippostrongylus brasiliensis infection leads to the development of emphysema associated with the induction of alternatively activated macrophages. Eur. J. Immunol. 38: 479-488. 23. Chenery, A. L., R. Alhallaf, Z. Agha, J. Ajendra, J. E. Parkinson, M. M. Cooper, B. H. K.

615 Chan, R. M. Eichenberger, L. A. Dent, A. A. B. Robertson, A. Kupz, D. Brough, A. Loukas, T. E. Sutherland, J. E. Allen, and P. R. Giacomin. 2019. Inflammasome-independent role for NLRP3 in controlling innate antihelminth immunity and tissue repair in the lung. J. Immunol. 203: 2724-2734.

24. Chen, F., Z. Liu, W. Wu, C. Rozo, S. Bowdridge, A. Millman, N. Van Rooijen, J. F.

620 Urban, T. A. Wynn, W. C. Gause, and W. C. Gause. 2012. An essential role for TH2-type responses in limiting acute tissue damage during experimental helminth infection. Nat. Med. 18: $260-266$.

25. Sutherland, T. E., N. Logan, D. Rückerl, A. A. Humbles, S. M. Allan, V. Papayannopoulos, B. Stockinger, R. M. Maizels, and J. E. Allen. 2014. Chitinase-like proteins promote IL-17-mediated neutrophilia in a tradeoff between nematode killing and host damage. Nat. Immunol. 15: 1116-1125.

26. Urban, J. F., N. Noben-Trauth, D. D. Donaldson, K. B. Madden, S. C. Morris, M. Collins, and F. D. Finkelman. 1998. IL-13, IL-4Ralpha, and Stat6 are required for the expulsion of the gastrointestinal nematode parasite Nippostrongylus brasiliensis. Immunity 8: 255-264.

630 27. Mearns, H., W. G. C. Horsnell, J. C. Hoving, B. Dewals, A. J. Cutler, F. Kirstein, E. Myburgh, B. Arendse, and F. Brombacher. 2008. Interleukin-4-promoted T helper 2 responses enhance Nippostrongylus brasiliensis-induced pulmonary pathology. Infect. Immun. 76: 5535-5542.

28. Oeser, K., C. Schwartz, and D. Voehringer. 2015. Conditional IL-4/IL-13-deficient mice 635 reveal a critical role of innate immune cells for protective immunity against gastrointestinal helminths. Mucosal Immunol. 8: 672-682.

29. Barner, M., M. Mohrs, F. Brombacher, and M. Kopf. 1998. Differences between IL-4R $\alpha-$ deficient and IL-4-deficient mice reveal a role for IL-13 in the regulation of Th2 responses. Curr. Biol. 8: 669-672.

640 30. McKenzie, G. J., C. L. Emson, S. E. Bell, S. Anderson, P. Fallon, G. Zurawski, R. Murray, R. Grencis, and A. N. . McKenzie. 1998. Impaired development of Th2 cells in IL13-deficient mice. Immunity 9: 423-432.

31. Naba, A., K. R. Clauser, S. Hoersch, H. Liu, S. A. Carr, and R. O. Hynes. 2012. The 
matrisome: In silico definition and in vivo characterization by proteomics of normal and tumor extracellular matrices. Mol. Cell. Proteomics 11: M111.014647.

32. Sutherland, T. E., D. Rückerl, N. Logan, S. Duncan, T. A. Wynn, and J. E. Allen. 2018. Ym1 induces RELM $\alpha$ and rescues IL-4R $\alpha$ deficiency in lung repair during nematode infection. PLOS Pathog. 14: e1007423.

33. Thawer, S., J. Auret, C. Schnoeller, A. Chetty, K. Smith, M. Darby, L. Roberts, R. M.

650 Mackay, H. J. Whitwell, J. F. Timms, J. Madsen, M. E. Selkirk, F. Brombacher, H. W. Clark, and W. G. C. Horsnell. 2016. Surfactant protein-D is essential for immunity to helminth infection. PLoS Pathog. 12: e1005461.

34. Kim, L. K., R. Morita, Y. Kobayashi, S. C. Eisenbarth, C. G. Lee, J. Elias, E. E. Eynon, and R. A. Flavell. 2015. AMCase is a crucial regulator of type 2 immune responses to inhaled house dust mites. Proc. Natl. Acad. Sci. U. S. A. 112: E2891-E2899.

35. Knipper, J. A., S. Willenborg, J. Brinckmann, W. Bloch, T. Maaß, R. Wagener, T. Krieg, T. Sutherland, A. Munitz, M. E. Rothenberg, A. Niehoff, R. Richardson, M. Hammerschmidt, J. E. Allen, and S. A. Eming. 2015. Interleukin-4 receptor $\alpha$ signaling in myeloid cells controls collagen fibril assembly in skin repair. Immunity 43: 803-816.

660 36. Sutherland, T. E., D. Rückerl, N. Logan, S. Duncan, T. A. Wynn, and J. E. Allen. 2018. Ym1 induces RELM $\alpha$ and rescues IL-4R $\alpha$ deficiency in lung repair during nematode infection. PLOS Pathog. 14: e1007423.

37. Krljanac, B., C. Schubart, R. Naumann, S. Wirtz, S. Culemann, G. Krönke, and D. Voehringer. 2019. RELM $\alpha$-expressing macrophages protect against fatal lung damage and reduce parasite burden during helminth infection. Sci. Immunol. 4: 3814.

38. Wan, H., K. H. Kaestner, S. L. Ang, M. Ikegami, F. D. Finkelman, M. T. Stahlman, P. C. Fulkerson, M. E. Rothenberg, and J. A. Whitsett. 2004. Foxa2 regulates alveolarization and goblet cell hyperplasia. Development 131: 953-964.

39. McKenzie, G. J., A. Bancroft, R. K. Grencis, and A. N. J. McKenzie. 1998. A distinct 670 role for interleukin-13 in Th2-cell-mediated immune responses. Curr. Biol. 8: 339-342. 40. Kumar, R. K., C. Herbert, M. Yang, A. M. L. Koskinen, A. N. J. McKenzie, and P. S. Foster. 2002. Role of interleukin-13 in eosinophil accumulation and airway remodelling in a mouse model of chronic asthma. Clin. Exp. Allergy 32: 1104-1111.

41. Munitz, A., E. B. Brandt, M. Mingler, F. D. Finkelman, and M. E. Rothenberg. 2008.

675 Distinct roles for IL-13 and IL-4 via IL-13 receptor alpha1 and the type II IL-4 receptor in asthma pathogenesis. Proc. Natl. Acad. Sci. U. S. A. 105: 7240-7245.

42. Bao, K., and R. L. Reinhardt. 2015. The differential expression of IL-4 and IL-13 and its 
impact on type-2 immunity. Cytokine 75: 25-37.

43. LaPorte, S. L., Z. S. Juo, J. Vaclavikova, L. A. Colf, X. Qi, N. M. Heller, A. D. Keegan, and K. C. Garcia. 2008. Molecular and structural basis of cytokine receptor pleiotropy in the interleukin-4/13 system. Cell 132: 259-272.

44. White, S. R., L. D. Martin, R. Stern, B. Laxman, and B. A. Marroquin. 2010. Expression of IL-4/IL-13 receptors in differentiating human airway epithelial cells. Am. J. Physiol. Lung Cell. Mol. Physiol. 299: L681-93.

685 45. Zhen, G., S. W. Park, L. T. Nguyenvu, M. W. Rodriguez, R. Barbeau, A. C. Paquet, and D. J. Erle. 2007. IL-13 and epidermal growth factor receptor have critical but distinct roles in epithelial cell mucin production. Am. J. Respir. Cell Mol. Biol. 36: 244-253.

46. Park, S. W., C. Verhaeghe, L. T. Nguyenvu, R. Barbeau, C. J. Eisley, Y. Nakagami, X. Huang, P. G. Woodruff, J. V. Fahy, and D. J. Erle. 2009. Distinct roles of FOXA2 and 690 FOXA3 in allergic airway disease and asthma. Am. J. Respir. Crit. Care Med. 180: 603-610. 47. Chen, G., H. Wan, F. Luo, L. Zhang, Y. Xu, I. Lewkowich, M. Wills-Karp, and J. A. Whitsett. 2010. Foxa2 programs Th2 cell-mediated innate immunity in the developing lung. J. Immunol. 184: 6133-6141.

48. Ilumets, H., P. Rytilä, I. Demedts, G. G. Brusselle, A. Sovijärvi, M. Myllärniemi, T.

695 Sorsa, and V. L. Kinnula. 2007. Matrix metalloproteinases $-8,-9$ and -12 in smokers and patients with Stage 0 COPD. Int. J. COPD 2: 369-379.

49. Imaoka, H., T. Hoshino, S. Takei, T. Kinoshita, M. Okamoto, T. Kawayama, S. Kato, H. Iwasaki, K. Watanabe, and H. Aizawa. 2008. Interleukin-18 production and pulmonary function in COPD. Eur. Respir. J. 31: 287-297.

700 50. Neill, D. R., S. H. Wong, A. Bellosi, R. J. Flynn, M. Daly, T. K. A. Langford, C. Bucks, C. M. Kane, P. G. Fallon, R. Pannell, H. E. Jolin, and A. N. J. McKenzie. 2010. Nuocytes represent a new innate effector leukocyte that mediates type-2 immunity. Nature 464: 13671370.

51. Lawrence, R. A., C. A. Gray, J. Osborne, and R. M. Maizels. 1996. Nippostrongylus

705 brasiliensis: cytokine responses and nematode expulsion in normal and IL-4-deficient mice. Exp. Parasitol. 84: 65-73.

52. Herrera, J. A., V. Mallikarjun, S. Rosini, M. A. Montero, C. Lawless, S. Warwood, R. O’Cualain, D. Knight, M. A. Schwartz, and J. Swift. 2020. Laser capture microdissection coupled mass spectrometry (LCM-MS) for spatially resolved analysis of formalin-fixed and 710 stained human lung tissues. Clin. Proteomics 17: 24.

53. Cox, J., and M. Mann. 2008. MaxQuant enables high peptide identification rates, 
individualized p.p.b.-range mass accuracies and proteome-wide protein quantification. Nat. Biotechnol. 26: 1367-1372.

54. Goeminne, L. J. E., K. Gevaert, and L. Clement. 2018. Experimental design and dataanalysis in label-free quantitative LC/MS proteomics: A tutorial with MSqRob. J. Proteomics 171: 23-36.

55. Perez-Riverol, Y., A. Csordas, J. Bai, M. Bernal-Llinares, S. Hewapathirana, D. J. Kundu, A. Inuganti, J. Griss, G. Mayer, M. Eisenacher, E. Pérez, J. Uszkoreit, J. Pfeuffer, T. Sachsenberg, Ş. Yilmaz, S. Tiwary, J. Cox, E. Audain, M. Walzer, A. F. Jarnuczak, T.

720 Ternent, A. Brazma, and J. A. Vizcaíno. 2019. The PRIDE database and related tools and resources in 2019: Improving support for quantification data. Nucleic Acids Res. 47: D442D450.

56. Chang, J., R. Garva, A. Pickard, C. Y. C. Yeung, V. Mallikarjun, J. Swift, D. F. Holmes, B. Calverley, Y. Lu, A. Adamson, H. Raymond-Hayling, O. Jensen, T. Shearer, Q. J. Meng, 725 and K. E. Kadler. 2020. Circadian control of the secretory pathway maintains collagen homeostasis. Nat. Cell Biol. 22: 74-86.

57. Ritchie, M. E., B. Phipson, D. Wu, Y. Hu, C. W. Law, W. Shi, and G. K. Smyth. 2015. limma powers differential expression analyses for RNA-sequencing and microarray studies. Nucleic Acids Res. 43: e47-e47.

730 58. Robinson, M. D., D. J. McCarthy, and G. K. Smyth. 2009. edgeR: A Bioconductor package for differential expression analysis of digital gene expression data. Bioinformatics 26: $139-140$. 
bioRxiv preprint doi: https://doi.org/10.1101/2020.10.14.337949; this version posted October 14, 2020. The copyright holder for this preprint (which was not certified by peer review) is the author/funder, who has granted bioRxiv a license to display the preprint in perpetuity. It is made available under aCC-BY-NC-ND 4.0 International license.

\section{Supplemental figures}

735

A

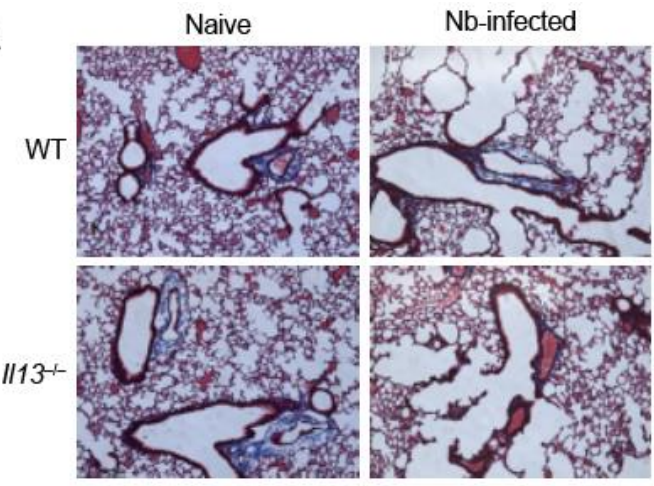

$\mathrm{B}$

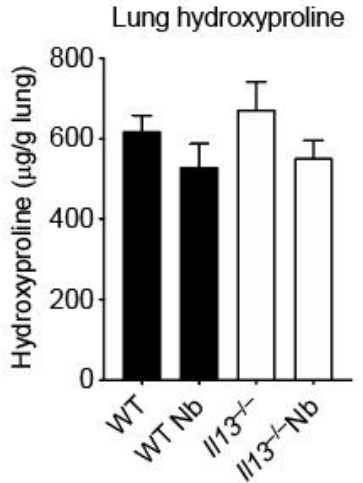

Figure S1 Analysis of total collagen in the lungs of $I l 13^{-/-}$mice after $N$. brasiliensis infection on D6pi. (A) Lung sections were prepared and stained with Masson's trichrome Stain and imaged to visualise collagen. (B) Hydroxyproline levels from whole lungs were measured. Data are representative (A) or pooled (mean \pm SEM in B) from 2 individual experiments with 4-5 mice per group (per experiment).

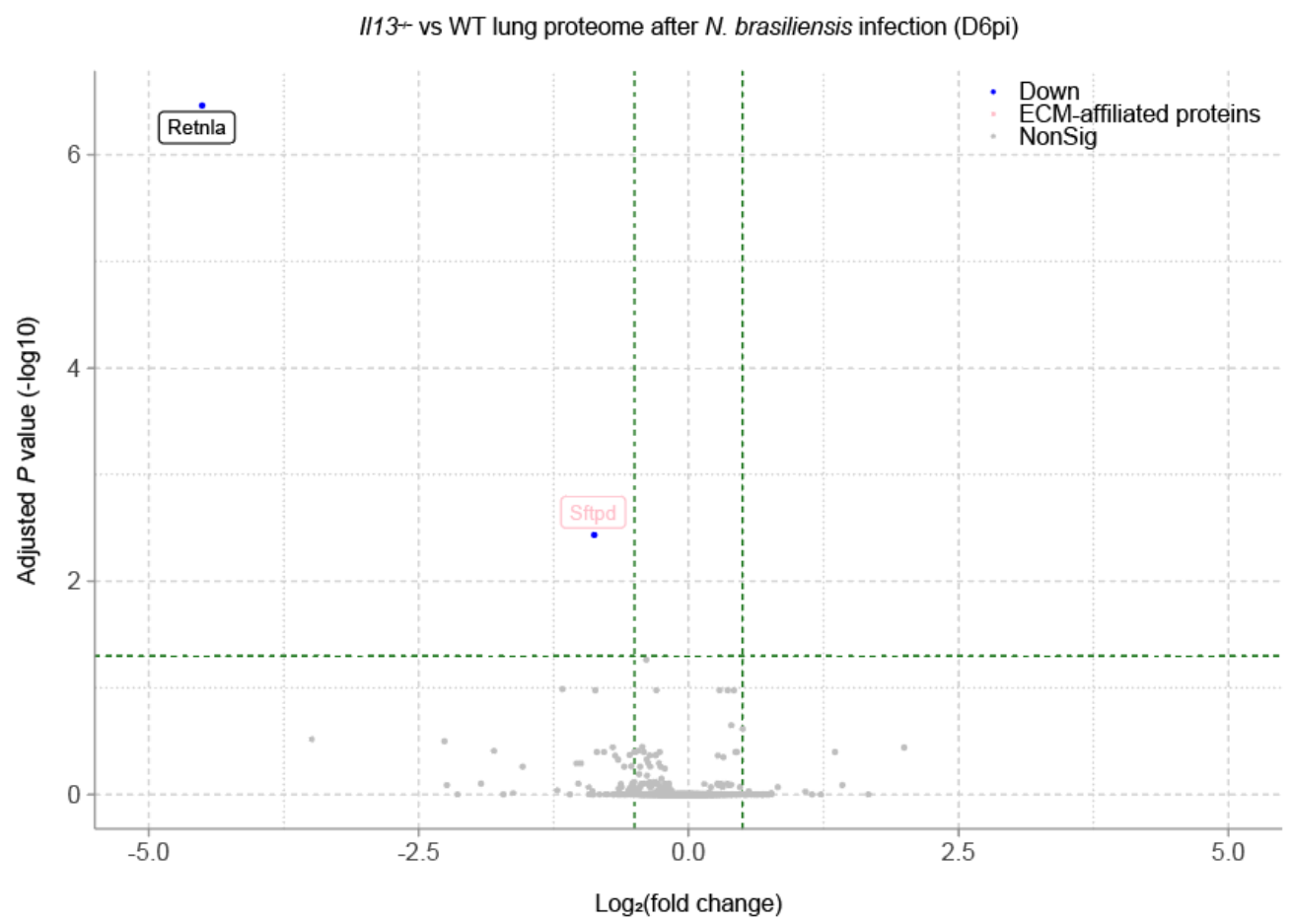

Figure S2 Volcano plot of differentially expressed proteins (by adjusted $P$ value) in the lungs of $N$. brasiliensisinfected $I l 13^{-/-}$mice compared to infected WT mice on D6pi. 